\title{
Cognitive Dissonance and Buyers' Coping Mechanisms: A Comparative Study of US and Indian Consumers
}

\author{
Qazi Asif Zameer ${ }^{1} \&$ Raj Devasagayam ${ }^{2}$ \\ ${ }^{1}$ Faculty in Marketing, FORE School of Management, New Delhi, India \\ ${ }^{2}$ Faculty in Marketing, School of Business, Siena College, Loudonville, USA \\ Correspondence: Raj Devasagayam, Faculty in Marketing, School of Business, Siena College, 515 Loudon Road, \\ Loudonville, New York - 12211, USA. Tel: 518-782-6863. E-mail: rdevasagayam@siena.edu
}

Received: February 16, 2015

Accepted: April 9, 2015

Online Published: April 20, 2015

doi:10.5430/ijba.v6n3p1

URL: http://dx.doi.org/10.5430/ijba.v6n3p1

\begin{abstract}
This study empirically examined difference in the cognitive dissonance resolution behavior of US and Indian consumers. The data was collected through an online survey through the use of convenience and snowball sampling techniques. The use of ANOVA provided the results that indicate that Indian consumers are more cautious and risk-averse in their approach to purchases than US consumers. US consumers demonstrate a higher level of individualistic thinking and are more confident of their choices while Indian consumers have more collectivistic thinking and want peer approval of their choices. US consumers came out to be more aggressive in their post purchase dissonance reducing behavior while Indian consumers appeared to be more willing to compromise with a bad purchase.
\end{abstract}

Keywords: cognitive dissonance, post purchase dissonance, dissonance reducing behavior, coping mechanism, USA and Indian consumers

\section{Introduction}

USA and India are two of the largest consumer markets in the world. All the major companies of the world have had their presence in the US for a long time while India has been a relatively new market for most of them. India embarked on the path of liberalization and globalization only in 1991 and still is considered as an emerging market. Most of the contemporary practices and thoughts have originated from the US based on the research and understanding of US consumers. Many Multinational Corporations tried to replicate those practices in India and found, to their dismay, that the consumer behavior of Indians was markedly different from consumers in USA. The purpose of this study was to come to a better understanding of why consumers feel remorse or regret after making a purchase (cognitive dissonance) and to find if there is any difference in the cognitive dissonance behavior of US and Indian consumers. We wanted to understand the levels of remorse consumers feel after making different purchases because a better understanding of the reasoning behind returning a product will ultimately assist companies with how they market their product and facilitate with pricing plans in both of these markets. We studied many variables in hopes of better understanding when and why consumers feel a sense of regret. The questions on our survey were designed to gain insight as to what the "average" customer feels after making a purchase decision and how they cope with making bad purchases. Our sample included respondents of different demographics in both countries so we could obtain unbiased results from many different respondents; due to the large respondent pool (145 in USA and 114 in India) and a good representation from different demographics; we feel that our results are an adequate representation of the population of both the countries.

The questions that were searched related to consumers and allowed us to measure their level of regret associated with different purchases. Through our research we were able to understand if remorse after buying a big ticket item (high involvement purchase) was larger than the regret associated with purchasing a smaller ticket item (low involvement purchase). By analyzing the data we came to a better understanding of buyer's remorse and the way consumers feel after their decision to make a purchase. The study helped us to understand in which variables there were significant differences between the US and Indian consumers and in which variables their perceptions / actions were similar. 


\section{Literature Review}

We conducted a literature review of the secondary information we thought would be most beneficial and would give us a better insight into our research problem which was to come to a better understanding of why consumers feel remorse or regret after making a purchase (cognitive dissonance) and to find if there is any difference in the cognitive dissonance behavior of US and Indian consumers. One direction of the literature review was taken up in the area of post purchase satisfaction and dissatisfaction while another direction of the literature review was to see the impact of culture on consumers' post purchase response, particularly in the case of US and Indian consumers.

The pioneering work in the field of post purchase dissatisfaction is the cognitive dissonance theory propounded by Festinger (1957), which maintains that individuals enhance their opinions of decisions after they have made them. Earlier most of the researchers opined that cognitive dissonance is seen only when the consumer in more involved with the purchase: either the price of the product is high as per his/her perspective, or the decision can have long term impact on his life / health / family etc. Oliver (2006) says that satisfaction depends on the closeness between expectations and the product perceived performance. This raises a question that do the consumers have no expectations in the case of low involvement purchases. Later on, researchers started looking at cognitive dissonance through the prism of the involvement of the consumer in the purchase: high or low. Gbadamosi (2009) suggests that three main conditions exist for arousal of dissonance in purchases: the decision involved in the purchase must be important, such as, involvement of a lot of money or psychological cost and be personally relevant to the consumer; the consumer has a freedom in selecting among the alternatives, finally; the decision involvement must be irreversible. For a typical purchase, the degree of cognitive dissonance felt by more involved purchasers is less than that felt by less involved purchasers. More planned and less spontaneous buying behavior is associated with a higher degree of cognitive dissonance (George and Edwards 2009). All of these studies provided us the understanding to capture the variables influencing cognitive dissonance in both the high involvement and low involvement purchase decisions.

The next direction for our research work was to study the literature where comparative analysis of Indian and US consumers were done. There are very few such studies though there are many papers which have done such study in the context of US and Asian customers. Two studies (Nisbett, Peng, and Choi 2001) and (Miyamoto, Nisbett, and Masuda 2006) concluded that cross-cultural psychology describes cultural differences in style of thinking, with Asian societies characterized by holistic thinking and Western societies characterized by analytic thinking. Holistic thinking involves an orientation to the context or filed as a whole, whereas analytic thinking involves a detachment of the object from its context and a focus on attributes of the subject (Monga and John 2007). This gap in literature about comparative analysis of US and Indian consumers gave us the added motivation for this study.

One of the main pieces of our research, we used to develop our scales, was from previous work by Duhachek (2005). In his report he outlined findings relating to how people cope with stress and negative emotions. He found that people cope with these emotions in different ways whether it is through the consolation or reassurance of others or the desire and need to fix the problem and look for solutions. The scale he used to collect this data was very useful to us in that we could tweak the variables to better suit our own research question regarding buyer's remorse. For example, in his scale one of his variables addressed if the respondent "tries to make a plan of action" when confronted with a negative situation. We found this variable to be suiting to our research topic but in order to make it more relevant to buyer's remorse we changed it to "try to make a plan of action to return the product". In another study, Cummings and Venkatesan (1975) concluded that pre-decisional determinants and post-decisional determinants support the dissonance-based predictions while information seeking behavior does not. Powers and Jack (2013) examined the influence of two forms of cognitive dissonance (emotional dissonance and product dissonance) on the frequency of product returns. The third part of our research, to assess dissonance reducing behavior, emerged from such literature.

The literature review was very helpful in giving us background research, clarifying what exactly we should be focusing on in our study. After doing it, not only did we get the inputs for our variables and scales, we also arrived at the following research questions:

1: Are there significant difference between the factors leading to cognitive dissonance between US and Indian consumers?

2: Are the US and Indian consumers significantly different in their risk assessment and risk attitudes during their purchase decisions? Does the level of involvement in purchase decision significantly alter the risk attitudes?

3: Do US and Indian consumers significantly differ in post purchase dissonance reducing behavior? 


\section{Methodology}

The research design we used consisted of mainly descriptive and some exploratory data. The exploratory research gave us qualitative data which allowed us to further analyze the research topic and come to a better understanding of how our respondents are thinking. The exploratory research helped us to fine tune the quantitative questions for the descriptive research. The descriptive research data allowed us to come to conclusions from our findings. To gain this type of data we used a seven point scale where people could relate themselves to specific variables with 1 being never and 7 being always. Our survey was sent out to approximately 300 respondents, 259 completed responses were used for the empirical analyses (USA: 145 and India: 114) yielding an 86.33 incidence rate.

\subsection{Scales and Validation}

Our scale, which tested the amount of overall remorse, was taken from a previous research study by Duhachek (2005). These scales measured how consumers carry on and cope with their negative and stressful emotions. We modified Duhachek's scale to better suit our own research study by making the variables relate to how consumers deal with making a purchase they regret. Other scales that were used in our research survey had variables that we created ourselves to measure the amount of buyer's remorse present in big ticket items compared to smaller purchases. We did this by creating one set of questions for both types of purchases. We believe this is a valid approach because this allowed us to compare results and measure the remorse level for each type of purchase. We also further questioned the level of remorse in relation to these purchases by finding out from the respondent how often they purchase and return products of each type.

Scale reliability was checked and results indicated that the scale for variables influencing cognitive dissonance in high involvement purchases is a thirteen-item scale with good psychometric properties (Cronbach's Alpha 0.705). The analogous 13-item scale used for low involvement purchase had a Cronbach's Alpha of 0.775. The scale of variables measuring buyer's remorse had a Cronbach's Alpha value of 0.791 (10-item scale). In all the three scales, the Cronbach's Alpha was much higher than 0.60 which is the generally accepted level for reliability.

\subsection{Survey Design}

An on-line data collection program was used to collect data from both USA and India samples. A convenience based random sample was generated using snowballing technique to garner larger number of responses. Several rounds of pretesting helped us fine-tune the survey for content and flow. Resultant survey was seen as being easy to navigate and complete between 5 and 7 minutes. The format of the survey consisted of a set of questions on a scale regarding "big ticket items", then another page of questions involving "smaller purchases", leading to a third scale which measured the amount of general and overall buyer's remorse and coping mechanisms, and finally a section obtained demographics of the respondent.

\subsection{Sample Profile}

We received 145 completed and useable responses from USA and 114 completed and usable responses from India. This is just about enough critical mass to enable the analysis and generalization of the results. A summary of the sample profile is given below (Table 1).

Table 1. Comparison between the sample profile of US and Indian respondents

\begin{tabular}{|c|c|c|c|c|}
\hline \multirow[b]{2}{*}{ Gender } & \multicolumn{2}{|l|}{ USA } & \multicolumn{2}{|c|}{ INDIA } \\
\hline & & & & \\
\hline Males & 57 & $39.3 \%$ & 82 & $71.9 \%$ \\
\hline Females & 88 & $60.7 \%$ & 32 & $28.1 \%$ \\
\hline Total & 145 & $100 \%$ & 114 & $100 \%$ \\
\hline \multicolumn{5}{|l|}{ Age } \\
\hline 18-29 years old & 90 & $62.1 \%$ & 87 & $76.3 \%$ \\
\hline $30-49$ years old & 33 & $22.8 \%$ & 18 & $15.8 \%$ \\
\hline 50-64 years old & 18 & $12.4 \%$ & 9 & $7.9 \%$ \\
\hline 65 years and older & 4 & $2.8 \%$ & 0 & 0 \\
\hline Total & 145 & $100 \%$ & 114 & $100 \%$ \\
\hline
\end{tabular}




\begin{tabular}{lllll}
\hline Highest level of education & & & & \\
\hline Some high school & 1 & $0.7 \%$ & 0 & $0 \%$ \\
\hline High school graduate & 9 & $6.2 \%$ & 0 & $0 \%$ \\
\hline Some college & 15 & $10.3 \%$ & 4 & $0 \%$ \\
\hline Currently in college & 69 & $47.6 \%$ & 59 & $51.8 \%$ \\
\hline College graduate & 35 & $24.1 \%$ & 51 & $44.7 \%$ \\
\hline Post graduate degree & 16 & $11 \%$ & 114 & $100 \%$ \\
\hline Total & 145 & $100 \%$ & - \\
\hline Race & & & & \\
\hline Caucasian & 138 & $95 \%$ & 111 & \\
\hline Asian & - & - & & \\
\hline Annual household income & & & \\
\hline Less than $\$ 10,000$ & 16 & $11.0 \%$ & & \\
\hline$\$ 10,001-\$ 25,000$ & 8 & $5.5 \%$ & & \\
\hline$\$ 25,001-\$ 50,000$ & 15 & $10.3 \%$ & & \\
\hline$\$ 50,001-\$ 75,000$ & 27 & $18.6 \%$ & & \\
\hline$\$ 70,001-\$ 100,000$ & 26 & $17.9 \%$ & & \\
\hline$\$ 101,000+$ & 53 & $36.6 \%$ & & \\
\hline Total & 145 & $100.0 \%$ & & \\
\hline & & & & \\
\hline
\end{tabular}

Summary of findings from the sample profiles:

1. The sample was skewed towards females in USA and towards males in India.

2. The sample includes more respondents in the age group of 18-29 years. This skew is more in case of Indian sample. This is an outcome of online data collection method where most of the respondents were students or young professionals.

3. The sample includes largely current college students in USA and graduates / post graduates in India. This is also an outcome of the main source of respondents in both these countries.

4. Almost $100 \%$ of the respondents belong to Caucasian race in USA and to Asian race in India. This is along expected lines.

5. Annual Household income (HHI) - There is no response from Indian respondents for this question. It can be attributed to their reluctance in sharing this data. However considering that the data has been collected online, all of the Indian respondents have access to computers / internet and they can safely be assumed to be part of Indian middle / upper class. The respondents from USA mostly belong to upper and upper middle class.

Thus the overall respondents in both the countries are relatively younger in age, well educated and from the consuming class. According to us, the sample adequately represents the customers who engage in big ticket purchases.

\section{Data Analysis and Findings}

First part of the survey was related to understanding cognitive dissonance behavior in the case of high involvement purchases. The data was subjected to One-way ANOVA to compare mean perceptions between US and Indian consumers in respect of variables influencing cognitive dissonance in the case of high involvement purchase situations. The findings can be seen below (Tables 2 and 3). 
Table 2. Comparative analysis of US and Indian consumers for high involvement purchases (Descriptives)

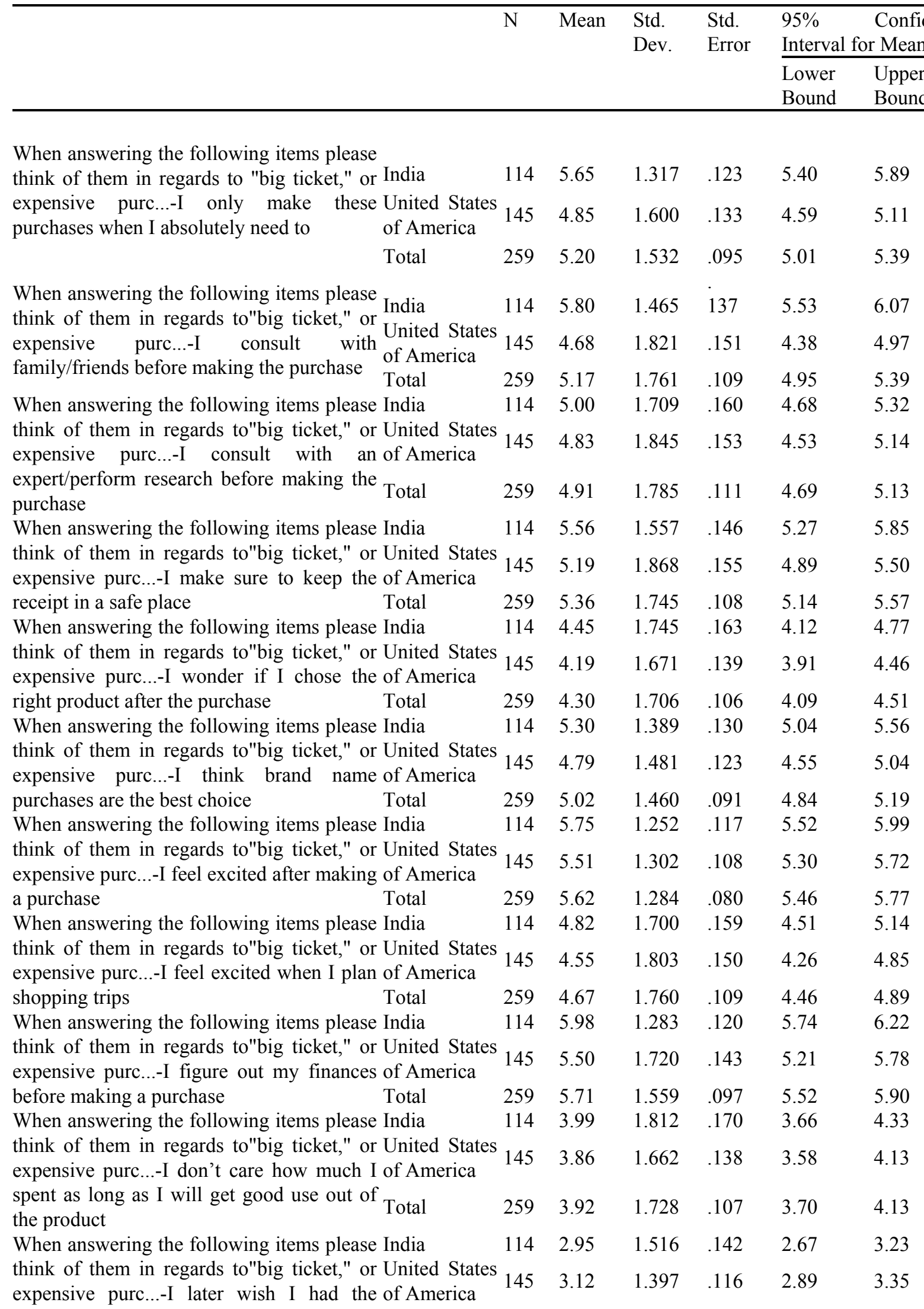




\begin{tabular}{|c|c|c|c|c|c|c|}
\hline $\begin{array}{l}\text { money instead or the proauct i recently Total } \\
\text { purchased }\end{array}$ & 259 & 3.04 & 1.450 & .090 & 2.87 & 3.22 \\
\hline When answering the following items please India & 114 & 3.20 & 1.730 & .162 & 2.88 & 3.52 \\
\hline $\begin{array}{l}\text { think of them in regards to"big ticket," or United States } \\
\text { expensive purc...-I feel upset if people do of America }\end{array}$ & 145 & 2.54 & 1.404 & .117 & 2.31 & 2.77 \\
\hline not compliment me on my recent purchase Total & 259 & 2.83 & 1.588 & .099 & 2.64 & 3.02 \\
\hline When answering the following items please India & 114 & 2.04 & 1.346 & .126 & 1.79 & 2.29 \\
\hline $\begin{array}{l}\text { think of them in regards to"big ticket," or United States } \\
\text { expensive purc...-I make purchases when I of America }\end{array}$ & 145 & 2.43 & 1.610 & .134 & 2.16 & 2.69 \\
\hline know I can’t afford it & 259 & 2.26 & 1.509 & .094 & 2.07 & 2.44 \\
\hline
\end{tabular}

Table 3. Comparative analysis of US and Indian consumers for high involvement purchases (ANOVA)

\begin{tabular}{|c|c|c|c|c|c|}
\hline & $\begin{array}{l}\text { Sum } \\
\text { Squares }\end{array}$ & of df & $\begin{array}{l}\text { Mean } \\
\text { Square }\end{array}$ & $\mathrm{F}$ & Sig. \\
\hline When answering the following items Between Groups & 40.933 & 1 & 40.933 & 18.631 & $.000 * * *$ \\
\hline please think of them in regards to"big Within Groups & 564.627 & 257 & 2.197 & & \\
\hline $\begin{array}{l}\text { ticket," or expensive purc...-I only make } \\
\text { these purchases when I absolutely need to Total }\end{array}$ & 605.560 & 258 & & & \\
\hline When answering the following items Between Groups & 80.400 & 1 & 80.400 & 28.693 & $.000 * * *$ \\
\hline $\begin{array}{l}\text { please think of them in regards to"big Within Groups } \\
\text { ticket," or expensive purc...-I consult }\end{array}$ & 720.125 & 257 & 2.802 & & \\
\hline $\begin{array}{l}\text { with family/friends before making the Total } \\
\text { purchase }\end{array}$ & 800.525 & 258 & & & \\
\hline When answering the following items Between Groups & 1.748 & 1 & 1.748 & .548 & .460 \\
\hline $\begin{array}{l}\text { please think of them in regards to"big Within Groups } \\
\text { ticket," or expensive purc...-I consult }\end{array}$ & 820.028 & 257 & 3.191 & & \\
\hline $\begin{array}{l}\text { with an expert/perform research before Total } \\
\text { making the purchase }\end{array}$ & 821.776 & 258 & & & \\
\hline When answering the following items Between Groups & 8.657 & 1 & 8.657 & 2.865 & $.092 *$ \\
\hline please think of them in regards to"big Within Groups & 776.663 & 257 & 3.022 & & \\
\hline $\begin{array}{l}\text { ticket," or expensive purc...-I make sure } \\
\text { to keep the receipt in a safe place }\end{array}$ & 785.320 & 258 & & & \\
\hline When answering the following items Between Groups & 4.353 & 1 & 4.353 & 1.499 & .222 \\
\hline please think of them in regards to"big Within Groups & 746.157 & 257 & 2.903 & & \\
\hline $\begin{array}{l}\text { ticket," or expensive purc...-I wonder if I } \\
\text { chose the right product after the purchase }\end{array}$ & 750.510 & 258 & & & \\
\hline When answering the following items Between Groups & 16.285 & 1 & 16.285 & 7.843 & $.005 * * *$ \\
\hline please think of them in regards to"big Within Groups & 533.653 & 257 & 2.076 & & \\
\hline $\begin{array}{l}\text { ticket," or expensive purc...-I think brand } \\
\text { name purchases are the best choice }\end{array}$ & 549.938 & 258 & & & \\
\hline When answering the following items Between Groups & 3.801 & 1 & 3.801 & 2.318 & .129 \\
\hline please think of them in regards to"big Within Groups & 421.357 & 257 & 1.640 & & \\
\hline $\begin{array}{l}\text { ticket," or expensive purc...-I feel excited Total } \\
\text { after making a purchase }\end{array}$ & 425.158 & 258 & & & \\
\hline When answering the following items Between Groups & 4.751 & 1 & 4.751 & 1.537 & .216 \\
\hline please think of them in regards to"big Within Groups & 794.353 & 257 & 3.091 & & \\
\hline $\begin{array}{l}\text { ticket," or expensive purc...-I feel excited } \\
\text { when I plan shopping trips }\end{array}$ & 799.104 & 258 & & & \\
\hline When answering the following items Between Groups & 15.069 & 1 & 15.069 & 6.326 & $.013 * *$ \\
\hline please think of them in regards to"big Within Groups & 612.213 & 257 & 2.382 & & \\
\hline
\end{tabular}


ticket," or expensive purc...-I figure out

my finances before making a purchase

When answering the following items Between Groups

please think of them in regards to"big Within Groups

ticket," or expensive purc...-I don't care

how much I spent as long as I will get Total

good use out of the product

When answering the following items Between Groups

please think of them in regards to"big Within Groups

ticket," or expensive purc...-I later wish I

had the money instead of the product I Total

recently purchased

When answering the following items Between Groups

please think of them in regards to"big Within Groups

ticket," or expensive purc...-I feel upset if

people do not compliment me on my Total

recent purchase

When answering the following items Between Groups

please think of them in regards to"big Within Groups

ticket," or expensive purc...-I make Total

627.282

258

1.181

$1 \quad 1.181$

768.950

257

2.992

.395

.530

$770.131 \quad 258$

1.842

1

1.842

.875

.350

540.691

257

2.104

542.533

258

28.124

1

28.124

$11.613 .001 * * *$

622.401

257

2.422

650.525

258

purchases when I know I can't afford it

Note: $*$ denotes p: 0.10 or lesser, ${ }^{* *}$ denotes p: 0.05 or lesser, ${ }^{* * *}$ denotes p: 0.01 or lesser

From Table 3, we see that out of 13 parameters, there are significant differences (at varying level of confidence) in mean perceptions of seven parameters between US and Indian consumers while involved in big ticket purchase. The parameters where there is very high level of significant difference (at $99 \%$ confidence level) are - making big ticket purchases only when they are absolutely needed, consulting family / friends before making expensive purchase, trusting the brand names, and feeling upset if people do not compliment on the purchase. We can see a significant difference (at 95\% confidence level) in the response for figuring out the finances before making expensive purchase, and making purchases even when the customer could not afford them. Further, at $90 \%$ confidence level, there is a significant difference in making sure that receipt is kept in a safe place. The higher mean response from Indian customers in the case of the all of these parameters (as seen from Table 2) can be attributed to more risk-averse nature of Indian customers with regards to big ticket purchase. The Indian customers have less disposable incomes and big ticket purchases are more risky for them. Such purchases are more infrequent in India and people mitigate the risk by consulting family / friends or going for established brand names. The parameter of other's appreciation towards the expensive purchase has come out as less important in both the countries; still the Indian response is significantly higher conveying a higher need for social approval in India and a stronger individualistic behavior in USA. Regarding the parameter of buying big ticket items even when it is not affordable, though the responses in both the countries have tilted towards lower frequency; the Indian response is significantly closer to 'never'; again reinforcing the first parameter that Indian customers are more conservative and more need driven than their US counterparts.

The parameters where there is no statistical difference in responses from the two countries are - consulting expert / performing market research before a big ticket purchase, having negative thoughts after the purchase, feeling excited after the purchase, feeling excited while planning the shopping trip, not caring how much was spent as long as the customer got good value, and regretting having spent money on that purchase. Interestingly, the responses tended toward higher frequency on negative thoughts, as well as sense of excitement in post purchase behavior.

The second part of the survey was related to understand cognitive dissonance behavior in the case of low involvement purchases. The data was subjected to One-way ANOVA to compare mean perceptions between US and Indian consumers in respect of variables influencing cognitive dissonance in the case of low involvement purchase situations. The findings can be seen below. (Tables 4 and 5) 
Table 4. Comparative analysis of US and Indian consumers for low involvement purchases (Descriptives)

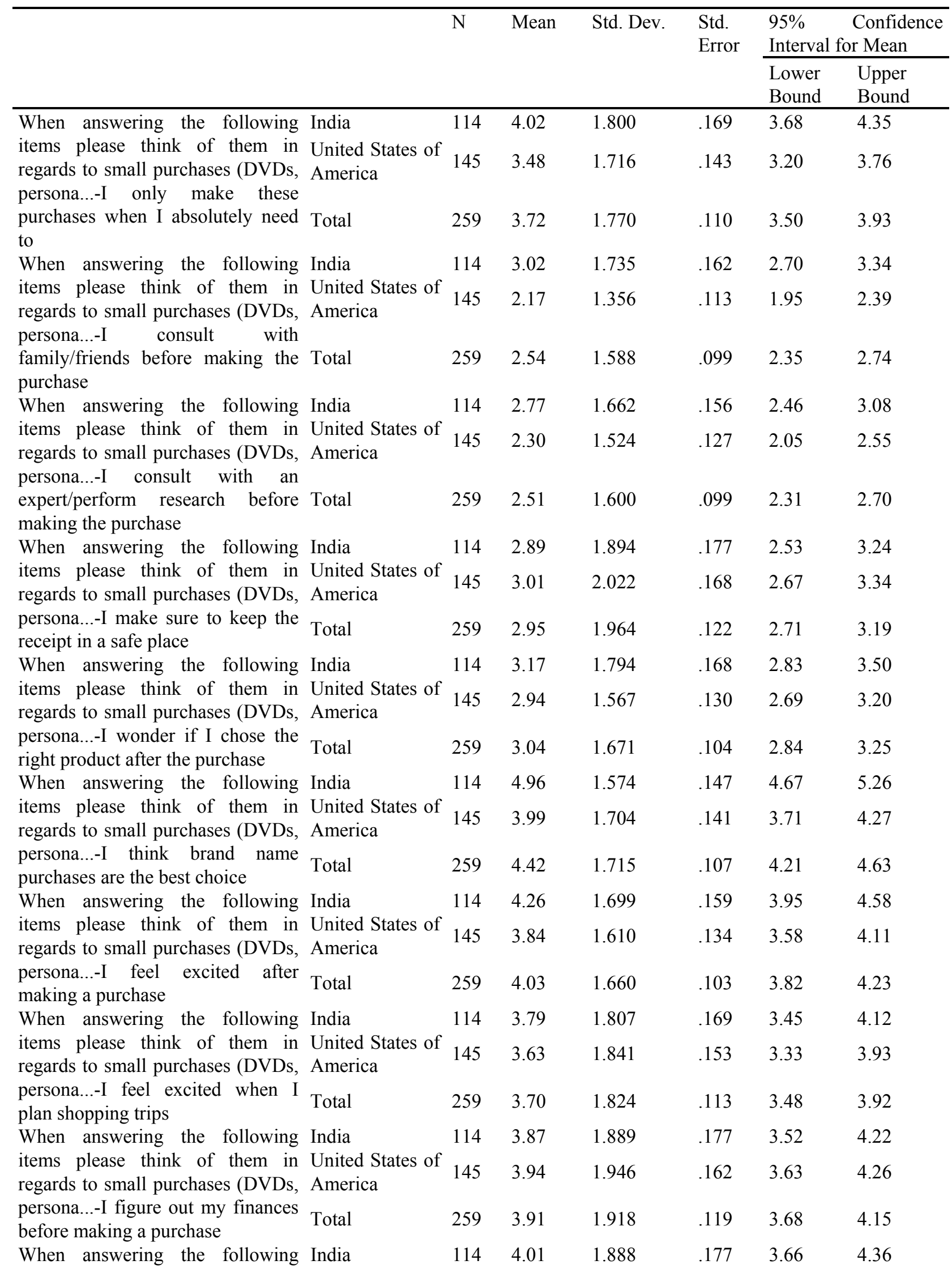




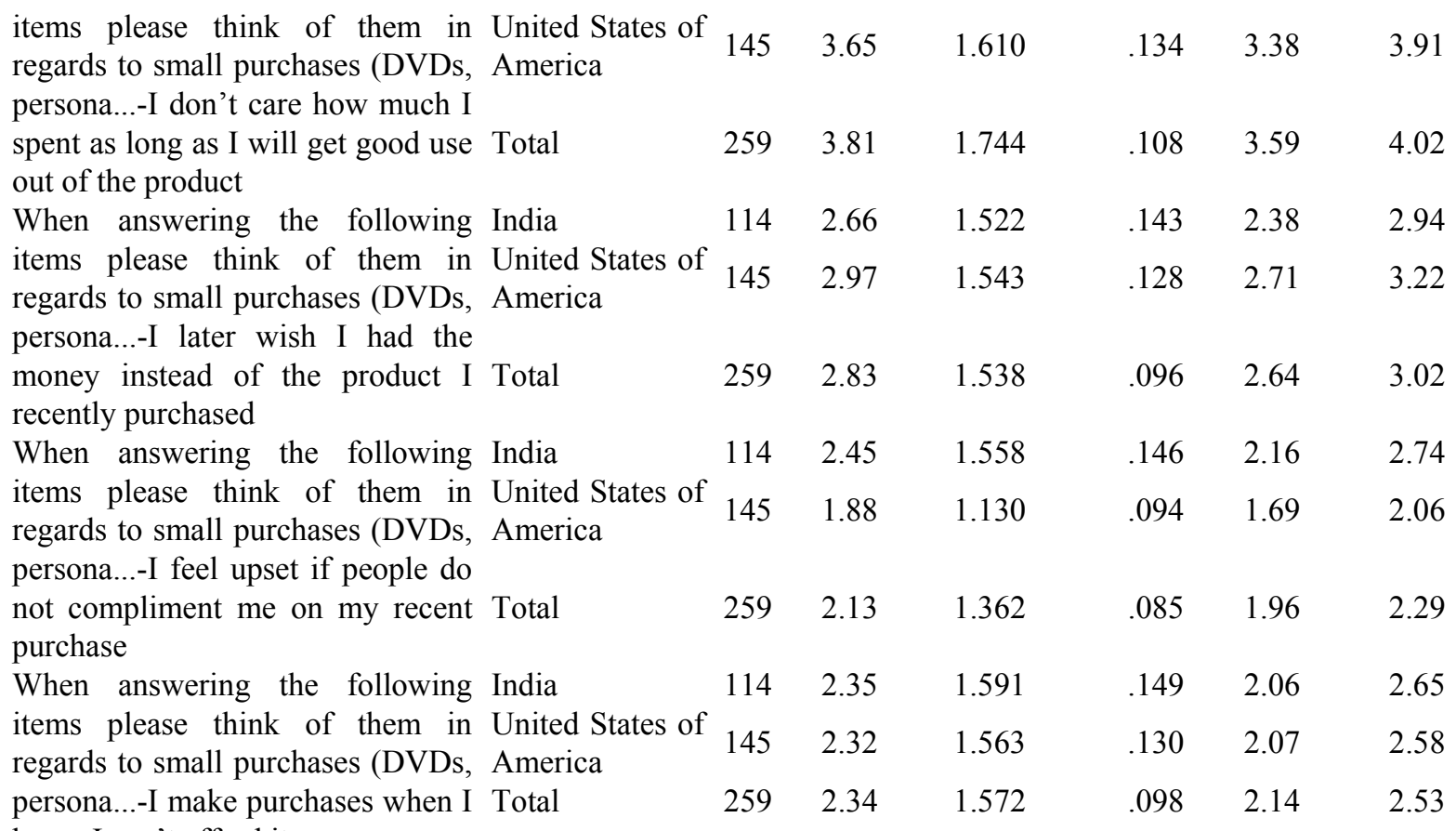

know I can't afford it

Table 5. Comparative analysis of US and Indian consumers for low involvement purchases (ANOVA)

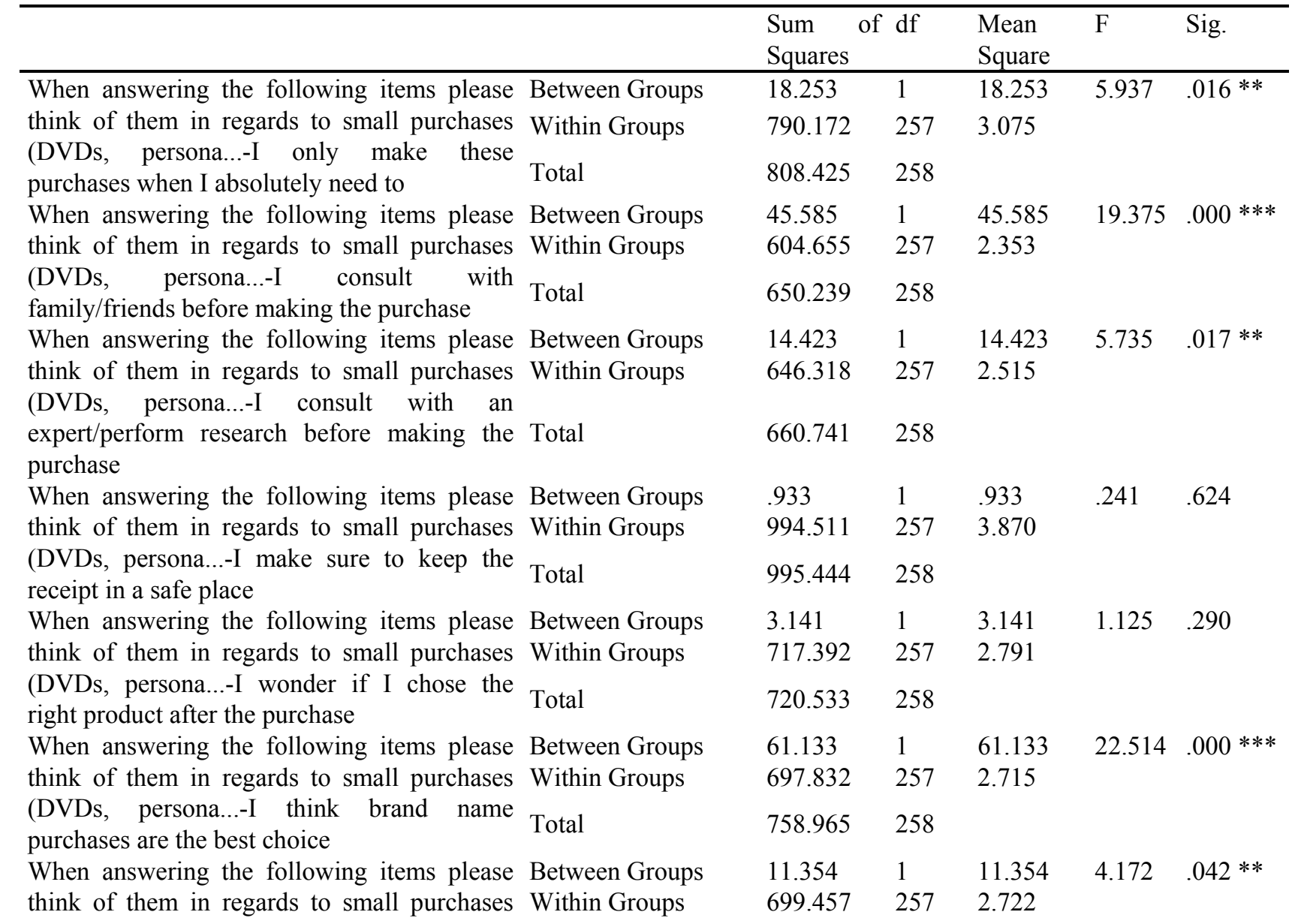


(DVDs, persona...-I feel excited after making a purchase

When answering the following items please think of them in regards to small purchases (DVDs, persona...-I feel excited when I plan shopping trips

When answering the following items please Between Groups think of them in regards to small purchases Within Groups (DVDs, persona...-I figure out my finances before making a purchase When answering the following items please Between Groups think of them in regards to small purchases Within Groups (DVDs, persona...-I don't care how much I spent as long as I will get good use out of the Total product

When answering the following items please Between Groups think of them in regards to small purchases Within Groups (DVDs, persona...-I later wish I had the money instead of the product I recently Total purchased

When answering the following items please Between Groups think of them in regards to small purchases Within Groups (DVDs, persona...-I feel upset if people do not compliment me on my recent purchase

Total

When answering the following items please think of them in regards to small purchases (DVDs, persona...-I make purchases when I know I can't afford it

$\begin{array}{lllll}710.811 & 258 & & & \\ 1.673 & 1 & 1.673 & .502 & .479 \\ 856.837 & 257 & 3.334 & & \\ 858.510 & 258 & & & \\ .373 & 1 & .373 & .101 & .751 \\ 948.585 & 257 & 3.691 & & \\ 948.958 & 258 & & & \\ 8.294 & 1 & 8.294 & 2.747 & .099 * \\ 776.053 & 257 & 3.020 & & \\ & & & & \\ 784.347 & 258 & & & \\ & & & & \\ 6.040 & 1 & 6.040 & 2.568 & .110 \\ 604.485 & 257 & 2.352 & & \\ & & & & \\ 610.525 & 258 & & & \\ & & & & \\ 20.846 & 1 & 20.846 & 11.699 & .001 * * * \\ 457.950 & 257 & 1.782 & & \\ 478.795 & 258 & & & \\ & & & & \\ .046 & 1 & .046 & .018 & .892 \\ 637.730 & 257 & 2.481 & & \\ 637.776 & 258 & & & \\ & & & & \end{array}$

Note: $*$ denotes p: 0.10 or lesser, ${ }^{* *}$ denotes p: 0.05 or lesser, ${ }^{* * *}$ denotes p: 0.01 or lesser

From Table 5, we can see that out of 13 parameters, there are significant differences (at varying level of confidence) in seven parameters between US and Indian consumers while involved in low ticket purchase. The parameters where there is very high level of significant difference (at 99\% confidence level) are - consulting family / friends before making small purchase, trusting the brand names, and feeling upset if people do not compliment on the purchase. The parameters having significant difference at $95 \%$ confidence level are - making low value purchases only when they are absolutely needed, consulting expert / performing research before doing the low value purchase, and feeling excited after the purchase. The parameter having significant difference at $90 \%$ confidence level is - not caring how much is spent on the product as long as the customer gets good value from it. The higher mean response from Indian customers in the case of the all of these parameters (as observed from Table 4) can again be attributed to more risk-averse nature of Indian customers with regards to even small purchase. The Indian customers have less disposable incomes and even small purchases are relatively more risky for them. Customers in India mitigate the risk by consulting family / friends, banking on experts / doing market research or going for established brand names. The Indian respondents giving high importance to purchasing even low involvement purchases only when they are truly needed may also mean a relatively less phenomena of impulse purchase behavior in India compared to the US. The feeling of excitement after making even a small purchase has come out to be significantly higher in India. Apart from basic necessities like food and grocery, any other purchase is seen as more of an indulgence in a country like India where the per capita income is much lower than the developed countries. Hence, any such purchase is a moment to celebrate and being excited on owning something. The parameter of other's appreciation towards the non-expensive purchase has come out as of very low importance in both the countries; still the Indian response is significantly higher conveying a higher need for social approval in India and a stronger individualistic behavior in USA.

The parameters where there is no statistical difference in responses from the two countries, as regards to small purchases, are -keeping the receipt safely, having negative thoughts after the purchase, feeling excited while planning the shopping trip, figuring out the finances before making the purchase, regretting having spent money on 
that purchase and making such purchases even when they were not affordable. The responses for all of these parameters have tilted towards lower frequency which is understandable considering that these are in context of small purchases.

We then proceeded to understand the level of post purchase remorse and dissonance reducing behavior of customers in both the countries. This data was also subjected to one-way ANOVA and the results can be seen below (Tables 6 and 7).

Table 6

\begin{tabular}{|c|c|c|c|c|c|c|c|c|c|}
\hline & & & & \multirow[t]{2}{*}{$\mathrm{N}$} & \multirow[t]{2}{*}{ Mean } & \multirow[t]{2}{*}{$\begin{array}{l}\text { Std. } \\
\text { Dev. }\end{array}$} & \multirow[t]{2}{*}{$\begin{array}{l}\text { Std. } \\
\text { Error }\end{array}$} & \multicolumn{2}{|c|}{$\begin{array}{l}95 \% \text { Confidence Interval } \\
\text { for Mean }\end{array}$} \\
\hline & & & & & & & & $\begin{array}{l}\text { Lower } \\
\text { Bound }\end{array}$ & Upper Bound \\
\hline \multirow{3}{*}{$\begin{array}{l}\text { When I make a purchase that I } \\
\text { later regret, I...-Try to make a } \\
\text { plan of action to return the } \\
\text { item/get my money back }\end{array}$} & India & & & 114 & 3.73 & 1.892 & .177 & 3.38 & 4.08 \\
\hline & $\begin{array}{l}\text { United } \\
\text { America }\end{array}$ & States & of & 145 & 4.54 & 1.760 & .146 & 4.25 & 4.83 \\
\hline & Total & & & 259 & 4.18 & 1.860 & .116 & 3.95 & 4.41 \\
\hline \multirow{3}{*}{$\begin{array}{l}\text { When I make a purchase that I } \\
\text { later regret, I...-Generate } \\
\text { potential solutions }\end{array}$} & India & & & 114 & 4.41 & 1.617 & .151 & 4.11 & 4.71 \\
\hline & $\begin{array}{l}\text { United } \\
\text { America }\end{array}$ & States & of & 145 & 4.72 & 1.543 & .128 & 4.47 & 4.98 \\
\hline & Total & & & 259 & 4.59 & 1.581 & .098 & 4.39 & 4.78 \\
\hline \multirow{6}{*}{$\begin{array}{l}\text { When I make a purchase that I } \\
\text { later regret, I...-Concentrate my } \\
\text { efforts to be able to keep the } \\
\text { product } \\
\text { When I make a purchase that I } \\
\text { later regret, I...-Try to step back } \\
\text { from the situation and be } \\
\text { objective }\end{array}$} & India & & & 114 & 4.32 & 1.570 & .147 & 4.02 & 4.61 \\
\hline & $\begin{array}{l}\text { United } \\
\text { America }\end{array}$ & States & of & 145 & 3.71 & 1.472 & .122 & 3.47 & 3.95 \\
\hline & Total & & & 259 & 3.98 & 1.542 & .096 & 3.79 & 4.17 \\
\hline & India & & & 114 & 4.32 & 1.484 & .139 & 4.05 & 4.60 \\
\hline & $\begin{array}{l}\text { United } \\
\text { America }\end{array}$ & States & of & 145 & 4.10 & 1.651 & . 137 & 3.83 & 4.37 \\
\hline & Total & & & 259 & 4.20 & 1.581 & .098 & 4.00 & 4.39 \\
\hline \multirow{3}{*}{$\begin{array}{l}\text { When I make a purchase that I } \\
\text { later regret, I...-Distract myself to } \\
\text { avoid thinking about it }\end{array}$} & India & & & 114 & 3.96 & 1.744 & .163 & 3.64 & 4.29 \\
\hline & $\begin{array}{l}\text { United } \\
\text { America }\end{array}$ & States & of & 145 & 2.90 & 1.660 & .138 & 2.63 & 3.18 \\
\hline & Total & & & 259 & 3.37 & 1.775 & .110 & 3.15 & 3.59 \\
\hline \multirow{3}{*}{$\begin{array}{l}\text { When I make a purchase that I } \\
\text { later regret, I...-Try to look at the } \\
\text { bright side of the purchase }\end{array}$} & India & & & 114 & 4.89 & 1.590 & .149 & 4.59 & 5.18 \\
\hline & $\begin{array}{l}\text { United } \\
\text { America }\end{array}$ & States & of & 145 & 4.43 & 1.628 & .135 & 4.16 & 4.69 \\
\hline & Total & & & 259 & 4.63 & 1.624 & .101 & 4.43 & 4.83 \\
\hline \multirow{3}{*}{$\begin{array}{l}\text { When I make a purchase that I } \\
\text { later regret, I...-Try to focus on } \\
\text { the positive aspects of the } \\
\text { purchase }\end{array}$} & India & & & 114 & 4.99 & 1.531 & .143 & 4.71 & 5.28 \\
\hline & $\begin{array}{l}\text { United } \\
\text { America }\end{array}$ & States & of & 145 & 4.58 & 1.597 & .133 & 4.32 & 4.84 \\
\hline & Total & & & 259 & 4.76 & 1.579 & .098 & 4.57 & 4.95 \\
\hline \multirow{3}{*}{$\begin{array}{l}\text { When I make a purchase that I } \\
\text { later regret, I...-Try to make the } \\
\text { best of the situation }\end{array}$} & India & & & 114 & 5.25 & 1.380 & .129 & 4.99 & 5.50 \\
\hline & $\begin{array}{l}\text { United } \\
\text { America }\end{array}$ & States & of & 145 & 4.77 & 1.586 & .132 & 4.51 & 5.03 \\
\hline & Total & & & 259 & 4.98 & 1.515 & .094 & 4.79 & 5.16 \\
\hline \multirow{3}{*}{$\begin{array}{l}\text { When I make a purchase that I } \\
\text { later regret, I...-Refuse to believe } \\
\text { that the regret even exists }\end{array}$} & India & & & 114 & 3.53 & 1.641 & .154 & 3.22 & 3.83 \\
\hline & $\begin{array}{l}\text { United } \\
\text { America }\end{array}$ & States & of & 145 & 2.82 & 1.711 & .142 & 2.54 & 3.10 \\
\hline & Total & & & 259 & 3.13 & 1.714 & .106 & 2.92 & 3.34 \\
\hline \multirow{3}{*}{$\begin{array}{l}\text { When I make a purchase that I } \\
\text { later regret, I...-Pretend that the } \\
\text { purchase never happened }\end{array}$} & India & & & 114 & 2.72 & 1.659 & .155 & 2.41 & 3.03 \\
\hline & $\begin{array}{l}\text { United } \\
\text { America }\end{array}$ & States & of & 145 & 2.35 & 1.627 & .135 & 2.08 & 2.62 \\
\hline & Total & & & 259 & 2.51 & 1.648 & .102 & 2.31 & 2.72 \\
\hline
\end{tabular}


Table 7. Comparative analysis of US and Indian consumers for dissonance reducing behaviour (ANOVA)

\begin{tabular}{|c|c|c|c|c|c|c|}
\hline & & Sum of Squares & $\mathrm{df}$ & Mean Square & $\mathrm{F}$ & Sig. \\
\hline When I make a purchase & Between Groups & 41.859 & 1 & 41.859 & 12.647 & $.000 * * *$ \\
\hline $\begin{array}{l}\text { that I later regret, I...-Try to } \\
\text { make a plan of action to }\end{array}$ & Within Groups & 850.612 & 257 & 3.310 & & \\
\hline $\begin{array}{l}\text { return the item/get my } \\
\text { money back }\end{array}$ & Total & 892.471 & 258 & & & \\
\hline When I make a purchase & Between Groups & 6.207 & 1 & 6.207 & 2.498 & .115 \\
\hline that I later regret, & Within Groups & 638.588 & 257 & 2.485 & & \\
\hline $\begin{array}{l}\text { I...-Generate potential } \\
\text { solutions }\end{array}$ & Total & 644.795 & 258 & & & \\
\hline When I make a purchase & Between Groups & 23.395 & 1 & 23.395 & 10.183 & $.002 * * *$ \\
\hline $\begin{array}{l}\text { that I later regret, } \\
\text { I...-Concentrate my efforts }\end{array}$ & Within Groups & 590.466 & 257 & 2.298 & & \\
\hline $\begin{array}{l}\text { to be able to keep the } \\
\text { product }\end{array}$ & Total & 613.861 & 258 & & & \\
\hline When I make a purchase & Between Groups & 3.318 & 1 & 3.318 & 1.329 & .250 \\
\hline that I later regret, I...-Try to & Within Groups & 641.640 & 257 & 2.497 & & \\
\hline $\begin{array}{l}\text { step back from the situation } \\
\text { and be objective }\end{array}$ & Total & 644.958 & 258 & & & \\
\hline When I make a purchase & Between Groups & 71.909 & 1 & 71.909 & 24.957 & $.000 * * *$ \\
\hline that I later regret, & Within Groups & 740.508 & 257 & 2.881 & & \\
\hline $\begin{array}{l}\text { I...-Distract myself to avoid } \\
\text { thinking about it }\end{array}$ & Total & 812.417 & 258 & & & \\
\hline When I make a purchase & Between Groups & 13.410 & 1 & 13.410 & 5.167 & $.024 * *$ \\
\hline that I later regret, I...-Try to & Within Groups & 667.007 & 257 & 2.595 & & \\
\hline $\begin{array}{l}\text { look at the bright side of the } \\
\text { purchase }\end{array}$ & Total & 680.417 & 258 & & & \\
\hline When I make a purchase & Between Groups & 10.829 & 1 & 10.829 & 4.401 & $.037 * *$ \\
\hline that I later regret, I...-Try to & Within Groups & 632.329 & 257 & 2.460 & & \\
\hline $\begin{array}{l}\text { focus on the positive } \\
\text { aspects of the purchase }\end{array}$ & Total & 643.158 & 258 & & & \\
\hline When I make a purchase & Between Groups & 14.711 & 1 & 14.711 & 6.551 & $.011 * *$ \\
\hline that I later regret, I...-Try to & Within Groups & 577.150 & 257 & 2.246 & & \\
\hline $\begin{array}{l}\text { make the best of the } \\
\text { situation }\end{array}$ & Total & 591.861 & 258 & & & \\
\hline When I make a purchase & Between Groups & 31.778 & 1 & 31.778 & 11.253 & $.001 * * *$ \\
\hline that I later regret, & Within Groups & 725.759 & 257 & 2.824 & & \\
\hline $\begin{array}{l}\text { 1...-Refuse to believe that } \\
\text { the regret even exists }\end{array}$ & Total & 757.537 & 258 & & & \\
\hline When I make a purchase & Between Groups & 8.623 & 1 & 8.623 & 3.202 & $.075 *$ \\
\hline that I later regret, & Within Groups & 692.080 & 257 & 2.693 & & \\
\hline $\begin{array}{l}\text { 1...-Pretend that the } \\
\text { purchase never happened }\end{array}$ & Total & 700.703 & 258 & & & \\
\hline
\end{tabular}

Note: $*$ denotes p: 0.10 or lesser, ${ }^{* *}$ denotes p: 0.05 or lesser, ${ }^{* * *}$ denotes p: 0.01 or lesser

As seen from Table 7, the parameters where there is very high significant difference (at $99 \%$ confidence level) in responses between the USA and Indian customers with regards to post purchase dissonance reducing behavior are trying to return the product / get the refund, concentrate on the effort to keep the product, distract self to avoid thinking about it, and refusing to believe that the regret even exists. The other parameters where significantly high difference (at 95\% confidence level) between US and Indian responses are - try to look at the bright side of the purchase, try to focus on the positive aspects of the purchase and try to make the best of the situation. Moreover, in one parameter (pretend that the purchase never happened), there is a significant difference at $90 \%$ confidence level. As seen from Table 6, the response from US customers on the first parameter is much higher than that from Indian 
customers which indicates that they are more confident and active in seeking a return / refund for a purchase which does not satisfy them. This is a reflection of more mature consumer market in USA than India as well as wider extension of such facility by the marketers due to higher level of competition. All the other seven parameters are opposite to the first parameter. These parameters are about dissonance reducing behavior and significantly higher mean responses in all of them form Indian customers suggests that Indian customers are more likely to convince themselves to live with the situation rather than go back to the selling company and seek a solution.

The parameters where there is no significant difference in responses between the US and Indian customers with regards to post purchase dissonance reducing behavior are - generate potential solutions and relooking at the problem objectively. Though these two questions are confirmatory to each other, the mean response is higher from US respondents for the first parameter while lower for the second parameter. It seems that the second question out of these two was not clearly understood by the respondents.

\section{Conclusions and Recommendations}

This study indicates that there are major differences between US and Indian consumers with respect to the variables which create cognitive dissonance. These results are very robust since they have been generated with the appropriate statistical analysis and at very high degree of confidence. These differences are more pronounced in the case of big ticket purchases though very much present in small ticket purchases as well. Global companies cannot think of replicating their successful practices and marketing models from USA in India. Indian customers are more risk averse. They do higher level of consultation from family, friends, experts and do more research before even relatively inexpensive purchases, not to mention high involvement purchases. The decision making and actual purchase in India is more collectivistic while the US consumers are more individualistic in their behavior. Companies should build in this aspect in their communication policies, store locations and store designs. Indian consumers put more trust in well-known brands. Companies should build up their brand credibility in India because this effort is likely to pay them higher return in Indian market. The decision of purchasing anything, apart from basic necessities, is a more carefully thought out process in India and is considered only when the need is clear and present. The company, wanting to do well in India, should research and understand the importance of the right branding strategy and appropriate occasion for the purchase of its products / services for the target segment and build its marketing activities around them. In the case of big ticket purchases, our study was able to identify an important need for others appreciation of the purchase in Indian consumers. The companies selling big ticket items like consumer durables, high end mobiles, fashion apparels, and automobiles etc. will do well to build the social acceptance angle in their communication strategies. We also identified the higher importance in Indian consumers of keeping the receipt safely. This can be an important dissonance reducing measure if the firm can assure the consumer that the receipt is not the only mechanism he / she has for obtaining the solution to a grievance. One way is having a permanent sticker on the product itself where the date of purchase, invoice number and customer assistance telephone number can be given. Electronic receipts are easier to archive (and access, when needed) and might alleviate some of the post purchase dissonance of the customers. Our study also concluded that US consumers are more confident in dealing with companies in asking for a product return or refund of their money. Indian consumers appeared more habitual of generating own dissonance reducing thoughts and more self-convincing in nature. Any firm which provides higher dissonance reducing measures could actually be able to leverage their efforts as a competitive advantage. As in any study of this magnitude that traverses nations and cultures, readers must be cautioned about certain limitations. The online survey mechanism has led to the sample being biased towards young, well educated and financially better-off customers. This method, though adequately appropriate for this study, may not reflect the true picture of the consumers, particularly in India. Further, this study has used the term big ticket and inexpensive purchase in a very generic way to get the responses. But within these two categories also there can be major differences in responses based on specific product purchase situation. Any future researcher may take up specific product categories in high and low involvement situations and try to assess the differences between US and Indian consumers' cognitive dissonance behavior.

In addition, we propose that culture could play a role in dealing with cognitive dissonance, and presents a rich area for future research. The framework developed by Geert Hofstede (1984) is commonly used to explore cultural differences in decision-making in international marketing literature. Hofstede (1984) proposes four dimensions on which a culture can be measured: power distance (cultural view of authority and subordination) individualism and collectivism (determinants of participants in decision-making), uncertainty avoidance (cultural view of risk behavior) and long-term orientation (view of time) and has developed indices that are useful in measuring and comparing cultures.

The Power Distance Index (PDI) for India (77) is far higher than the world average of 57 and USA (40). This suggests 
that the less powerful members of Indian society tend to be far more accepting of the inequality of power and wealth than in most other cultures. Indians score relatively low on the Individualism versus Collectivism (IDV) index (48) compared to the U.S. (91), but near the world average of 40. This suggests that Indians culturally tend toward collective solutions compared to the U.S., rather than being highly individualistic. The actions of an individual in India tend to be influenced by the opinion of others with which an individual is connected whether with family members or friends. India's low ranking (40) on the Uncertainty Avoidance (UAI) is far below the world average of 65, but similar to that of the U.S. (46). This indicates that the culture tends to be somewhat open to unstructured ideas and situations. The population may have fewer rules and regulations for use in attempting to control every unknown and unexpected event or situation and existing rules are often "bypassed." India's Long Term Orientation (LTO) Dimension score is 61, well above the world average of 48 and that for the U.S. (29). Indians tend to look toward the long term and the practical. Time is not as important as it is in the U.S. - people are often forgiven for a lack of punctuality. It is not unusual for Indians to let things "play out" rather than working to formulate and execute an exact plan of action.

To summarize, one can clearly see the parallels from prevalent culture in assessing and resolving cognitive dissonance. We believe that future research in this stream would benefit from including these cultural dimensions, something that was not the focus of our research.

\section{References}

Cummings, W. H., \& Venkatesan, M. (1975). Cognitive dissonance and consumer behavior: a review of the evidence. Advances in Consumer Behavior, 2(1), 210.

Duhachek, A. (2005). Coping: a multidimensional hierarchical framework of responses to stressful consumption episodes. Journal of Consumer Research, 32(1), 41-53. http://dx.doi.org/10.1086/426612

Festinger, L. (1957). A Theory of Cognitive Dissonance. Stanford University Press: Stanford, CA.

Gbadamosi, A. (2009). Cognitive dissonance: the implicit explication in low income consumers' shopping behavior for "low-involvement" grocery products. International Journal of Retailing and Distribution Management, 37(12), 1077-1095. http://dx.doi.org/10.1108/09590550911005038

George, B. P., \& Edward, M. (2009). Cognitive dissonance and purchase involvement in the consumer behavior context. IUP Journal of Marketing Management, 8(3/4), 7-24.

Hofstede, G. (1984). Culture's consequences: international differences in work-related values. In W.J. Lonner, and J.W. Berry (Eds.), The Sage Series on Cross-cultural Research and Methodology. Sage Publications: CA.

Miyamoto, Y., Nisbett, R. E., \& Masuda, T. (2006). Culture and the physical environment: holistic versus analytic

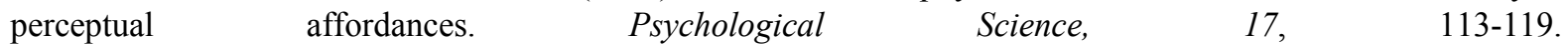
http://dx.doi.org/10.1111/j.1467-9280.2006.01673.x

Monga, B. A., \& John, D. R. (2007). Evaluation: the influence of analytic versus holistic thinking. Journal of Consumer Research, 33(4), 529-536. http://dx.doi.org/10.1086/510227

Nisbett, R. E., Peng, K., Choi, I., \& Norenzayan, A. (2001). Culture and systems of thought: holistic versus analytic cognition. Psychological Review, 108(2), 291-310. http://dx.doi.org/10.1037/0033-295X.108.2.291

Oliver, R. L. (2006). Customer Satisfaction Research. In R. Grover and M. Vriens (Eds.), Handbook of Marketing Research (pp. 569-87). Sage Publications: CA.

Powers, T., \& Jack, E. P. (2013). The influence of cognitive dissonance on retail product returns. Psychology and Marketing, 30(8), 724-735. http://dx.doi.org/10.1002/mar.20640 